\title{
The presentation order of cue and target matters in deception study
}

Guangheng Dong ${ }^{1 *}$, Yanbo $\mathrm{Hu}^{2}$ and Haiyan $\mathrm{Wu}^{1}$

The original article [1] was initially published with the following list of authors: Guangheng Dong, Yanbo $\mathrm{Hu}$, Qilin Lu and Haiyan Wu. This author list is now corrected as follows: Guangheng Dong, Yanbo Hu and Haiyan Wu. As Qilin Lu's contribution in writing the article did not fulfill the authorship criteria of being involved in drafting the manuscript for important intellectual content he has been removed from the author list. As such the authors' contributions section has been amended accordingly.

\section{Author details}

'Department of Psychology, Zhejiang Normal University, 688 of Yingbin Road, Jinhua City, Zhejiang Province, P.R.China. '2Department of Psychology, Royal Holloway, University of London, Egham, UK.

\section{Authors' contributions}

GD carried out the study. YH participated in the design of the study. HW performed the statistical analysis. All authors read and approved the final manuscript.

Received: 16 August 2011 Accepted: 16 August 2011

Published: 16 August 2011

\section{Reference}

1. Dong $G, H u Y, L u Q, W u H$ : The presentation order of cue and target matters in deception study. Behavioral and Brain Functions 2010, 6:63.

\section{doi:10.1186/1744-9081-7-36}

Cite this article as: Dong et al:: The presentation order of cue and target matters in deception study. Behavioral and Brain Functions 2011 7:36.

\footnotetext{
* Correspondence: dongguangheng@zjnu.edu.cn

'Department of Psychology, Zhejiang Normal University, 688 of Yingbin Road, Jinhua City, Zhejiang Province, P.R.China

Full list of author information is available at the end of the article
}

Submit your next manuscript to BioMed Central and take full advantage of:

- Convenient online submission

- Thorough peer review

- No space constraints or color figure charges

- Immediate publication on acceptance

- Inclusion in PubMed, CAS, Scopus and Google Scholar

- Research which is freely available for redistribution

\section{() Biomed Central}

